How to cite this article:

Ng, L. P., Choong, Y. O., Tee, C. W., Kuar, L. S., Teoh, S. Y., \& Chen, I. C. (2019). Green work climate and pro-environmental behaviour among academics: The mediating role of harmonious environmental passion. International Journal of Management Studies, 26(2), 77-97.

\title{
GREEN WORK CLIMATE AND PRO-ENVIRONMENTAL BEHAVIOUR AMONG ACADEMICS: THE MEDIATING ROLE OF HARMONIOUS ENVIRONMENTAL PASSION
}

\author{
LEE-PENG NG \\ *YUEN-ONN CHOONG \\ CHEE-WEE TEE \\ Department of Business, Faculty of Business and Finance \\ Universiti Tunku Abdul Rahman, Malaysia \\ LOK-SIN KUAR \\ SOK-YEE TEOH \\ Department of Economics, Faculty of Business and Finance \\ Universiti Tunku Abdul Rahman, Malaysia

\section{I-CHI CHEN} \\ Department of Marketing, Faculty of Business and Finance \\ Universiti Tunku Abdul Rahman, Malaysia \\ *Corresponding author: choongyo@utar.edu.my
}

\begin{abstract}
Environmental issues such as climate change, pollution, deforestation, and the loss of biodiversity are the concerns of society in different parts of the world today. As human activities have adverse impacts on the environment, developing pro-environmental behaviour in each individual is an essential aspect of protecting mother earth. The primary purpose of this research is to evaluate the influence of green work climate perceptions and harmonious environmental passion on pro-environmental behaviour (PEB). Additionally,
\end{abstract}


the mediating effect of harmonious environmental passion between green work climate and PEB is determined. A total of 167 academics from a private university in Malaysia participated in this study. The results from Partial Least Square - Structural Equation Modelling suggested that green work climate and harmonious environmental passion positively influence PEB. Apart from this, harmonious environmental passion partially mediates the relationship between green work climate and PEB. The results indicate that leaders should actively shape the perception of green work climate within their organisations through policies and procedures that support environmental sustainability efforts, as well as effectively communicate with their employees. Such efforts will lead to greater harmonious environmental passion, in turn, promoting pro-environmental behaviour among members.

Keywords: Green work climate, harmonious environmental passion, proenvironmental behaviour.

Received: 12/12/2019 Revised: 11/4/2020 Accepted: 12/4/2020 Published: 25/6/2020

\section{Introduction}

Environmental issues such as climate change, pollution, deforestation, and the loss of biodiversity are the concerns of society in different parts of the world today. A report by the United Nations (2019) showed that a $2^{\circ} \mathrm{C}$ temperature increase will cause more heatwaves, destroy the world's coral reef ecosystems, and accelerate sealevel rise due to melting glaciers and ice sheets. These detrimental environment conditions indicate an urgent need for different parties to take immediate action to curb environmental problems (Mustafa \& Saad, 2011). Many corporations have responded to the call for conservation of natural resources by implementing environmentally sustainable strategies (Thompson, Peteraf, Gamble \& Strickland III, 2018). Apart from that, higher education institutions (HEIs) are also embarking on building a green and sustainable campus (Lukman, Lozano, Vamberger \& Krajnc, 2013), inclusive of universities in Malaysia. Local universities should further improve their performance in the Universitas Indonesia (UI) GreenMetric World University Ranking, which is an indicator of university sustainable practices and performance (Sani, 2019). The improved recognition of the HEIs through the sustainability initiatives will be a crucial driver for competitiveness in the international arena. 
The goal of environmental sustainability requires the joint efforts of every member of an organisation; as such, there is a need to foster individual pro-environmental behaviour (PEB). PEB consists of any actions taken by employees to enhance an organisation's environmental performance (Robertson \& Barling, 2013). There have been burgeoning studies on PEB in recent years (Bamberg \& Möser, 2007; Lange \& Dewitte, 2019). For instance, numerous individual or person factors (e.g., environmental attitudes, habit, personal norm, intentions, and demographic variables) and organisational factors (e.g., leadership, social norms and organisational supports) have been identified as significant predictors of PEB (Botetzagias, Dima, \& Malesios, 2015; Li, Zhao, Ma, Shao \& Zhan, 2019; Norton, Parket, Zacher, \& Ashkanasy 2015a). Nevertheless, studies based on the employees' personal factors were the most widely conducted in the past (Norton et al., 2015a). Through their extensive reviews, Norton et al. (2015a) further stressed that more research is required for a better understanding of the mechanism through which organisationalrelated factors affect each individual's PEB.

The role of social norms in determining employee behaviour has been widely acknowledged (Bamberg \& Möser, 2007). Norton et al. (2015a) elucidated that green work climate entails shared perceptions among employees towards the cultural artefacts that are reflected through policies, procedures, and practices of environmental sustainability, as well as the typical behaviour of co-workers within an organisation (Norton, Zacher, \& Ashkanasy, 2014, 2015b). Research shows that green work climate allows shared norms among the members that are beneficiary in fostering PEB (Norton et al., 2015a).

Meanwhile, employees tend to be passionate about something that is considered socially important (Robertson \& Barling, 2013). Vallerand et al. (2003) categorised passion into two types: harmonious passion and obsession passion. Harmonious passion is regarded as a motivational concept that contributes to positive individual and organisational outcomes, which contradicts its counterpart, obsessive passion, that is often linked to undesired consequences (Burke, Astakhova \& Hang, 2015; Vallerand, Houlfort \& Forest, 2014). Recent studies have started to capture the role of harmonious environmental passion in explaining PEB (Robertson \& Barling, 2013). Harmonious environmental passion reflects an individual's autonomous motivation state, and is defined 
as "a positive emotion that results in an individual wanting to engage in pro-environmental behaviours" (Robertson \& Barling, 2013, p. 180). Despite increasing interest, research on passion for an activity remains scarce to date (Ho, Kong, Lee, Dubreuil \& Forest, 2018; Vallerand, 2012).

Norton et al. (2015a), through their comprehensive systematic reviews, concluded that organisational factors could affect one's motivational state (controlled or autonomous) and lead to the changes in employees' green (pro-environmental) behaviours. Nevertheless, an empirical study on the indirect influence on employees' perception of green work climate on PEB via harmonious environmental passion has yet to be conducted. Existing studies, such as those by Robertson and Barling (2013) as well as Afsar, Badir and Kiani (2016), mainly focus on the effects of leadership styles on harmonious environmental passion and PEB.

The present study concentrates on harmonious environmental passion instead of obsessive passion, as it can provide a better understanding of how the advantages of this form of passion can be harnessed to facilitate PEB among employees. The paucity of studies on harmonious environmental passion leads to the need for a better understanding of its antecedents and consequences in different cultural contexts. As such, this study aims to fill the gaps of the existing literature by evaluating the functions of green work climate and harmonious work passion on PEB. The mediating effect of harmonious environmental passion between green work climate and PEB will also be determined.

\section{Literature Review}

\section{Pro-environmental Behaviour}

The terms "pro-environmental behaviour", "environmental responsible behaviours" or "green behaviour" have been widely used to describe behaviours that protects the environment (Lee, Jan \& Yang, 2013). Pro-environmental behaviour encompasses any individual actions that minimise the negative environmental impact of human activities or to improve environmental quality (Kim, Kim \& Thapa, 
2018). Some scholars have found that pro-environmental behaviour is a form of pro-social behaviour which is intended to promote the wellbeing of an individual, group or organisation (Caprara \& Steca, 2007; Sawitri, Hadiyanto \& Hadi, 2015). The increasing awareness of the harmful impact of human activities and lifestyles on the environment has widened the focus of applied environmental psychology to PEB (Sawitri et al., 2015).

Across the globe, HEIs are more aggressively developing green campus in response to demands for environmental sustainability. In Malaysia, there are a total of 20 public universities and 41 private universities (Education Malaysia, 2020) with large number of students and staff, resulting in significant waste generation and high consumption of electricity, water, paper, and other materials (Ragazzi \& Ghidini, 2017). As such, many scholars are increasingly concerned about PEB among faculty members and students. The widely discussed antecedents of PEB in both academic and non-academic settings include demographic factors, personal value, environmental, environmental belief, environmental attitude, and norms (Cordano, Welcomer, Scherer, Pradenas, \& Parada, 2011; Mtutu, \& Thondhlana, 2016; Shafiei \& Maleksaeidi, 2020).

\section{Harmonious Environmental Passion and Pro-environmental Behaviour}

Passion refers to a strong inclination of an individual to invest time and money toward an activity that he or she likes or loves and views as important (Vallerand et al., 2003). Derived from the selfdetermination theory (SDT; Deci \& Ryan, 1985) which explains that behaviour is the consequences of autonomous and controlled motivations, Vallerand et al. (2003) introduced the Dualistic Model of Passion which distinguishes between obsessive passion and harmonious passion. Obsessive passion is the result of a controlled internalisation process, whereby a person engaged in an activity feels compelled to do so due to certain contingencies, such as to gain the feelings of social acceptance or self-esteem (Vallerand et al., 2003). This often leads to greater psychological distress (Houlfort, Philippe, Bourdeau \& Leduc, 2018). In contrast, harmonious passion occurs as a result of an autonomous internalisation activity into a person's identity; individuals freely perform an activity, rather than being 
forced to do so (Vallerand et al., 2003; 2007). Hence, a strong sense of harmonious passion is associated with positive affect (Philippe, Vallerand, Houlfort, Lavigne \& Donahue, 2010), psychological wellbeing (Vallerand, 2012), and job performance (Burke et al., 2015). Harmonious passion can be applied to the work and non-work spheres (Ho et al., 2018).

Harmonious environmental passion is essential in predicting PEB. This is because harmonious passion sparks positive emotion that motivates employees to behave pro-environmentally (Robertson \& Barling, 2013). Individuals with strong harmonious environmental passion are energetic and driven to make a difference by contributing to initiatives for environmental improvements. They can freely invest time and effort in pro-environmental activities, and their involvement will not lead to conflict with other activities in daily lives (Afsar et al., 2016; Robertson \& Barling, 2013). Empirically, harmonious environmental passion has been found to be a significant predictor of PEB among Canadian (Robertson \& Barling, 2013) and Thai employees (Afsar et al., 2016). In short, harmonious environment passion forms motivational force that enables employees to become actively involved in PEB. Hence, the following hypothesis is formulated.

$\mathrm{H}_{1}$ : Harmonious environmental passion is positively related to proenvironmental behaviour.

\section{Green Work Climate and Pro-environmental Behaviour}

The terms, 'green psychological climate' (Zhou, Zhang, Lyu \& Zhang, 2018), 'pro-environmental organisational climate' (Norton et al., 2015b), 'green organisational climate' (Zientara \& Zamojska, 2018) and 'green work climate' (Norton, Zacher \& Ashkanasy, 2014) are used interchangeably. All these constructs contribute to similar organisational outcomes, such as green product development performance (Zhou et al., 2018), pro-environmental behaviour (Zientara \& Zamojska, 2018; Norton et al., 2015b) and employee green behaviour (Norton et al., 2014).

The concept of green work climate is used in this study as it captures employee perceptions regarding the organisation and individual co-workers towards environmental sustainability (Norton et al., 2014). The view is built on theory of normative conduct established by Cialdini, Reno, and Kallgren (1990). The climate perception of 
an organisation is similar to injunctive norm, where if an employee perceives his or her organization's policies, practices, and procedures are supporting of and approve or disapprove of environmental behaviours (Cialdini et al., 1990; Norton et al., 2015b; 2014). Meanwhile, the climate perceptions of co-workers are related to descriptive norms; if an employee perceives that his or her co-workers behave in an environmental friendly manner at work, then this will further induce him or her to exhibit environmental behaviour (Norton et al., $2015 ; 2014)$.

A green work climate can be expressed as socially acceptable beliefs, attitudes and needs, with the support of organization and acceptable reasons for action towards environment (Norton et al., 2015b; Salancik \& Pfeffer, 1978). Succinctly, if employees perceive and interpret their organisation's policies, procedures, practices, work environment and company targets associated with environmental sustainability, this would further encourage and promote PEB among employees (Zhou et al., 2018). It is belief that individual's behaviour is partly influenced by the social system belief (Zientara \& Zamojska, 2018). Past empirical studies have evident that green work climate is significantly related to PEB (Das, Biswas, Munshi \& Uddin, 2019; Norton et al., 2015b; 2014; Robertson \& Carleton, 2017; Zientara \& Zamojska, 2018; Zhou et al., 2018). Pro-environmental behaviour can be known a type of voluntary behaviour or citizenship behaviour (Kim, Kim, Han, Jackson \& Ployhart, 2017; Paille \& Mejia-Morelos, 2014).

The initiatives taken by the universities in Malaysia to transform their institutions into green campus have included sustainability policy and planning, teaching, research, and promoting practices for environmental conservation (Hussin \& Velan, 2015). Sustainability initiatives and organisational values that have been effectively communicated to the employees will lead to the positive perception of green work climate and help promote PEB (Norton et al., 2014 Norton et al., 2015b). As such, if co-workers and organisations strongly support the demonstrations and practices that are environmentally friendly, employees would be more actively engage themselves in practicing PEB, such as energy savings, involve in recycling activities, water savings, etc. Thus, the hypothesis is proposed as follows.

$\mathrm{H}_{2}$ : Green work climate is positively related to pro-environmental behaviour. 


\section{Green Work Climate, Harmonious Environmental Passion and Pro- environmental Behaviour}

As indicated above, a green work climate covers employees' perceptions about organisational attributes and acceptable behavioural norms (Norton et al., 2014; 2015a). Jia, Liu, Chin, and $\mathrm{Hu}$ (2018) showed that green policies, procedures, and practices (i.e. organisational artefacts) were introduced through various functions of human resources management in the organisation were useful to arouse employees' harmonious green passion. Perception of work climate that supports environmental sustainability forms a psychological mechanism that can promote harmonious environmental passion among employees (Vallerand et al., 2014). The finding is consistent with Hardgrove and Howard's (2015) argument that employee passion can be discouraged or encouraged in the workplace.

Norton et al. (2015a) emphasized that the motivational state (autonomous or controlled) of an individual is the mechanism through which personal factors (e.g. personal norm, personality, and environmental attitude) and contextual factors can influence green behaviour or PEB. In the previous studies (Afsar et al., 2016; Robertson \& Barling, 2013), harmonious environmental passion not only has been found to have a significant direct effect on PEB, but also acts as a mediator between leadership styles (i.e. environmentalspecific transformational leaderships style and spiritual leadership) and PEB.

Based on the foundation of normative theory of conduct (Deci \& Ryan, 1985) and Dual Passion Model (Vallerand et al., 2003), this study postulated that when employees perceive that behaviours that are consistent with organisational expectations will be rewarded and supported, their inclination toward or preference for such activity (i.e. affective component of passion) are enhanced and they view that such involvement as important (i.e. cognitive component of passion) (Robertson \& Barling, 2013; Ho et al., 2018). Employees who have a harmonious passion are willing to go beyond personal needs for the collective benefits of the organisation and society (Robertson \& Barling, 2013). In addition, harmonious environmental passion creates positive emotion that becomes a motivational force that will further evoke PEB among employees. The above reviews lead to the following hypotheses. 
$\mathrm{H}_{3}$ : Green work climate is positively related to harmonious environmental passion.

$\mathrm{H}_{4}$ : Harmonious environmental passion mediates the relationship between green work climate and pro-environmental behaviour.

\section{Methodology}

\section{Procedure and Participants}

A total of 200 self-administrative questionnaires were distributed personally to the academic staff from different faculties in Universiti Tunku Abdul Rahman (UTAR), Kampar campus in Perak. UTAR is a young private university which is less than 20 years old, but is one of the leading universities in the country. UTAR was ranked 102 as the world's most sustainable university based on 2019 UI GreenMetric World University Ranking (UI Green Metric, 2019). Nonetheless, this ranking is still far behind other local public universities, such as Universiti Putra Malaysia, Universiti Malaysia, Universiti Malaysia Sabah, Universiti Utara Malaysia, Universiti Malaysia Pahang, and Universiti Teknologi Malaysia. UTAR has outlined its commitment towards sustainable practices and had initiated various projects to promote environmentally friendly behaviour. This study on UTAR provides better understanding on the effectiveness of such practices in shaping green work climate and behaviour among its academic staff.

In this study, a convenient sampling approach was the data collection process which took about three weeks to complete. A cover letter was enclosed with the questionnaire. The participants were informed that the participation was voluntary and the survey was anonymous. A total of 167 completed questionnaires were returned, for a response rate of 83.5 percent. The sample size of 167 exceeds the minimum sample size of 107 determined through G-Power analysis (Faul, Erdfelder, Buchner \& Lang, 2009) for two predictors, effect size $=0.15$, power $=0.95$, and alpha set at 0.05 .

The data from the returned questionnaires were entered and processed using Statistical Package for the Social Sciences (SPSS) version 23, and no missing data detected during the initial screening. Examination of construct validity and hypothesis testing were performed through SmartPLS 3.2.8 (Ringle, Wende \& Becker, 2015). 
Out of 167 samples, 87 (52.1\%) are females and $80(47.9 \%)$ are males. A large proportion of the participants are married (64.1\%) while 35.9 percent are still single. A majority of the respondents were 31 to 35 years old (41.3\%); other categories include 20 to 25 years (3.6\%), 26 to 30 years old (21\%), 36 to $40(14.4 \%), 46$ to 50 (9.6\%), 51 to $55(4.2 \%)$, and more than 55 years old (2.4\%). The participants were mainly from the faculty of business and finance $(61.7 \%)$, while the rest were from other faculties. A large group of participants had worked between five to 10 years in the university $(62.9 \%)$, followed less than five years $(32.9 \%)$ and more than 10 years $(4.2 \%)$. All the participants are Malaysians; 77.2 percent are Chinese, with 13.8 percent, Malays and 8.4 percent, Indians, and 0.6 percent, others.

\section{Measurements}

The pro-environmental behaviour scale consists of seven items adopted from Robertson and Barling (2013). All the items were measured on 5-point Likert scale, with response options range from never (1) to always (5). A sample item includes, "I save water whenever I can."

Harmonious environmental passion was measured with a 10-item scale developed by Robertson and Barling (2013). The respondents indicated their agreeableness from (1) strongly disagree to (5) strongly agree. The items include, "I get pleasure from taking care of the environment."

Green work climate has a total of eight items developed by Norton et al. (2014). Response options span from strongly disagree (1) to strongly agree (5). Four items are related to employee's perceptions toward his/her organisation; the sample item is, "My organisation believes it is important to protect the environment." Another four items measure employees' perceptions of their co-workers; the sample includes, "In my organisation, employees care about the environment."

\section{Results}

Through PLS-SEM analysis, the measurement model was first assessed, and then followed by the evaluation of the structural model. 


\section{Assessment of Measurement Model}

The internal consistency and construct validity of the key constructs in this study were examined via the PLS algorithm. Except for two indicators (Pro_Environment6 and Pro_Enviorment7) with outer loadings lower than 0.5 were deleted, the indicators as demonstrated in Table 1 were retained. Table 1 shows that the average variance extracted (AVE) for each construct surpassed the cut-off value of 0.50 (Bagozzi \& Yi, 1988; Bhatti \& Ur Rehman, 2019). The composite reliability for every construct was above 0.70 (Hair, Hult, Ringle, \& Sarstedt, 2017). In sum, the measurement model met the criteria for reliability and convergent validity.

Table 1

Composite Reliability and Convergent Validity of Key Constructs

\begin{tabular}{llccc}
\hline Construct & Items & $\begin{array}{c}\text { Outer } \\
\text { loadings }\end{array}$ & AVE & $\begin{array}{c}\text { Composite } \\
\text { reliability }\end{array}$ \\
\hline Green Work & C1 & 0.924 & 0.798 & 0.969 \\
& C2 & 0.912 & & \\
& C3 & 0.883 & & \\
& C4 & 0.925 & & \\
& C5 & 0.884 & & \\
Harmonious & C6 & 0.871 & & \\
Environmental & Env_Passion1 & 0.744 & 0.551 & 0.917 \\
Passion & Env_Passion2 & 0.692 & & \\
& Env_Passion3 & 0.802 & & \\
& Env_Passion4 & 0.802 & & \\
& Env_Passion5 & 0.671 & & \\
& Env_Passion6 & 0.678 & & \\
& Env_Passion7 & 0.676 & & \\
& Env_Passion8 & 0.788 & \\
\hline
\end{tabular}

(continued) 
IJMS 26(2), 77-97 (2019)

\begin{tabular}{llccc}
\hline Construct & Items & $\begin{array}{c}\text { Outer } \\
\text { loadings }\end{array}$ & AVE & $\begin{array}{c}\text { Composite } \\
\text { reliability }\end{array}$ \\
\hline Pro- & Env_Passion9 & 0.810 & & \\
environmental & Pro_environment1 & 0.647 & 0.510 & 0.838 \\
Behaviour & Pro_environment2 & 0.657 & & \\
& Pro_environment3 & 0.697 & \\
& Pro_environment4 & 0.818 & \\
& Pro_environment5 & 0.738 & & \\
& & & \\
\hline
\end{tabular}

Note. AVE = Average variance extracted

Fornell and Larcker criterion (Chin, 2010; Fornell \& Larcker, 1981) and heterotrait-monotrait ratio of correlations (HTMT, Henseler, Ringle \& Sarstedt, 2015) were used in determining the discriminant validity of the measurement model. Table 2 shows that the value of the square root of AVE for each construct is greater than the correlation values among the key variables in this study. Table 3 illustrates that the HTMT values were less than the threshold value of 0.85 (Kline, 2011) and 0.90 (Gold, Malhotra \& Segars, 2011). The results clearly indicate that the measurement model possessed adequate discriminant validity.

Table 2

Mean, Standard Deviation, and the Discriminant Validity of the Key Constructs

\begin{tabular}{|c|c|c|c|c|c|c|}
\hline & Construct & Mean & $\begin{array}{l}\text { Standard } \\
\text { deviation }\end{array}$ & 1 & 2 & 3 \\
\hline 1 & $\begin{array}{l}\text { Harmonious } \\
\text { environmental passion }\end{array}$ & 4.00 & 0.50 & 0.742 & & \\
\hline 2 & Green work climate & 3.93 & 0.77 & 0.442 & 0.893 & \\
\hline 3 & $\begin{array}{l}\text { Pro-environmental } \\
\text { behaviour }\end{array}$ & 3.73 & 0.74 & 0.633 & 0.433 & 0.707 \\
\hline
\end{tabular}

Note. Diagonals are the square root of AVE (bold) 
IJMS 26(2), 77-97 (2019)

Table 3

Heterotrait-Monotrait Ratio Analysis

\begin{tabular}{llrrr}
\hline & Construct & 1 & 2 & 3 \\
\hline 1 & Harmonious environmental passion & & & \\
2 & Green work climate & 0.450 & & \\
3 & Pro-environmental behaviour & 0.837 & 0.513 & \\
\hline
\end{tabular}

\section{Assessment of Structural Model}

The structural model was assessed through a bootstrapping procedure (5000 resamples). Table 4 indicates that harmonious environment passion $(\beta=0.674, p<0.001)$ and green work climate $(\beta=0.135, p$ $<0.005)$ were positively related to PEB. The results also indicated a significant positive relationship between green work climate and harmonious environment passion $(\beta=0.442, \mathrm{p}<0.001)$. Thus, $\mathrm{H}_{1^{\prime}} \mathrm{H}_{2^{\prime}}$ and $\mathrm{H}_{3}$ were supported.

Besides, harmonious environment passion was found to significantly mediated the link between green work climate and PEB $(\beta=0.298$, $\mathrm{p}<0.001), \mathrm{H} 4$ was supported. Variance accounted for (VAF) was calculated by determining the size of the indirect effect in relation to the total effect (Hair et al., 2017). Both directions of direct and indirect effects are positive (Zhao, Lynch \& Chen, 2010), and the VAF obtained was 68.8 percent $(0.298 / 0.433)$, which is between 20 percent and 80 percent, indicating a partial mediation (Hair et al., 2017). The result signifying harmonious environmental passion is a complementary partial mediator in this hypothesised relationship.

Harmonious environmental passion and the perception of green work climate explained 55.2 percent $\left(R^{2}=0.552\right)$ of $P E B$, indicating a substantial level of predictive accuracy based on the rules of thumbs proposed by Cohen's (1988). On the other hand, green work climate explained 19.6 percent of the harmonious work environment $\left(\mathrm{R}^{2}=\right.$ 0.196), suggesting a moderate level of predictive accuracy.

Next, the relative impact between the exogenous and endogenous variables was determined via effect size $\left(\mathrm{f}^{2}\right)$. Cohen's (1988) suggested that the effect size of $0.02,0.15$, and 0.35 , respectively represent small, 
medium, and large effect. As illustrated in Table 4, PEB substantially affected by harmonious environment passion $\left(\mathrm{f}^{2}=0.815\right)$ but weakly affected by green work climate $\left(\mathrm{f}^{2}=0.033\right)$. The effect of green work climate on harmonious environment passion is moderate $\left(\mathrm{f}^{2}=0.243\right)$.

The next assessment for model's predictive ability was by determining the Stone-Geisser's $\left(\mathrm{Q}^{2}\right)$ value, which is done through blindfolding procedure (Geisser, 1974; Stone, 1974) and the omission distance of 7 was chosen. As reported in Table 5, the $\mathrm{Q}^{2}$ value for PEB (0.257) and harmonious environment passion (0.094) are beyond the threshold value of zero (Hair et al., 2017), thus provide support for the model's predictive relevance. Table 4 shows that the variance inflation factor (VIF) values were lower than 3.3, an indication that the data are free from multicollinearity problem (Hair et al., 2017) and common method bias as per guideline by Kock (2015) for PLS-SEM.

\section{Table 4}

Results for the Hypothesised Model

\begin{tabular}{lcccccccc}
\hline \multicolumn{1}{c}{ Path } & Beta & $\mathrm{p}$-value & Results & $\mathrm{R}^{2}$ & $\mathrm{f}^{2}$ & $\mathrm{Q}^{2}$ & VIF \\
\hline $\begin{array}{l}\text { Direct effect } \\
\text { H1 }\end{array}$ HEP à PEB & 0.674 & 0.0001 & Supported & 0.552 & 0.815 & 0.257 & 1.243 \\
H2 & GWC à PEB & 0.135 & 0.0140 & Supported & & 0.033 & & \\
H3 & GWC à HEP & 0.442 & 0.0001 & Supported & 0.196 & 0.243 & 0.094 & 1.243 \\
Indirect (Mediation) effect & & & & & & & \\
H4 GWC à HEP à PEB & 0.298 & 0.0001 & Supported & & & & \\
\hline
\end{tabular}

Note. GWC = Green work climate, $\mathrm{HEP}=$ Harmonious environment passion, $\mathrm{PEB}=$ pro-environmental behaviour. Total effect $=0.135$ (direct effect $)+0.298$ (indirect effect) $=0.433$

\section{Discussion}

All hypotheses in this study were confirmed. As anticipated, harmonious environmental passion and green work climate have a significant direct relationship with PEB. Another notable finding was that a green work climate explains PEB indirectly through 
harmonious environmental passion. Corresponding with the notions put forward by a few authors (Afsar et al., 2016; Norton et al., 2015a), this study has shown that the organisational element (i.e., green work climate) produces a motivational force for the academics to freely partake in the pro-environmental activities. The results indicate that a green work climate is effective in fostering PEB when employees enjoy positive affective experience, in which they feel meaningful and joyful (i.e., harmonious passion).

Theoretically, this study extended the boundary of the existing literature by uncovering the mediating role of harmonious environmental passion in explaining the relationship between green work climate and PEB among academics in Malaysia. Practically speaking, the results indicated that the leaders should actively shape the perception of green work climate through well-designed policies and procedures that support environmental sustainability efforts in the university (Norton et al., 2015b). The administrators of the university must effectively communicate organisational expectations and desired behaviour to employees in order to develop a strong green work climate. In addition, the university can introduce rewards and recognition programme to academics who actively engage in environmental initiatives and research, as well as those who provide constructive suggestions for enhancing the environmental sustainability of the university. These practices reveal the organisational environmental values and further enhance shared perceptions that are beneficial in creating a green work climate that can enhance harmonious passion.

\section{Conclusion}

The present study provides evidence that green work climate, via the mediation of harmonious environmental passion, may improve PEB. Nevertheless, this study has limitations that need to be addressed. First, the sample of this study was drawn from a private university. Despite the sample size being adequate for performing the analysis via PLS-SEM, a larger sample involving academics from both private and public universities will enable better generalisation of the results. Second, the cross-sectional design nature of this research result makes it difficult to have absolute certainty in determining the direction of 
causality of the variables (Shadish, Cook, \& Campbell, 2002). Hence, future researchers can use a longitudinal study design to overcome such limitations. Nonetheless, the hypothesised relationships in this study were underscored by prior empirical evidence and theoretical supports.

Third, in the evaluation of one's inclination towards environmentally friendly activities, this study concentrated on a single type of passion (i.e., harmonious passion) described by the Dualistic Passion Model (Vallerand et al., 2003). Future researchers can evaluate the impacts of both harmonious passion and obsessive passion on environment towards PEB. Finally, the present study did not take into consideration the implications of personal factors (e.g. environmental awareness) and other situational variables (e.g. leadership style) that can affect harmonious environmental passion and PEB (Northon et al., 2015). Hence, future researchers should integrate these variables into the model to gain a broader perspective towards understanding PEB.

\section{Acknowledgements}

This research received no specific grant from any funding agency in the public, commercial, or non-profit sectors.

\section{References}

Afsar, B., Badir, Y., \& Kiani, U. S. (2016). Linking spiritual leadership and employee pro-environmental behavior: The influence of workplace spirituality, intrinsic motivation, and environment passion. Journal of Environmental Psychology, 45, 79-88.

Arezu Shafiei., \& Hamideh Maleksaeidi. (2020). Pro-environmental behavior of university students: Application of protection motivation theory. Global Ecology and Conservation, 22, e00908.

Bagozzi, R. P., \& Yi, Y. J. (1988). On the evaluation of structural equation models. Journal of the Academy of Marketing Science, 16(1), 74-94.

Bamberg, S., \& Möser, G. (2007). Twenty years after Hines, Hungerford, and Tomera: A new meta-analysis of psychosocial determinants of pro-environmental behaviour. Journal of Environmental Psychology, 27, 14-25. 
Bhatti, A., \& Ur Rehman, S. (2019). Perceived benefits and perceived risks effect on online shopping behavior with the mediating role of consumer purchase intention in Pakistan. International Journal of Management Studies, 26(1), 33-54.

Botetzagias, I., Dima, A., \& Malesios, C. (2015). Extending the theory of planned behavior in the context of recycling: the role of moral norms and of demographic predictors. Resources. Convervation \& Recyling, 95, 58-67.

Burke, R. J., Astakhova, M. N., \& Hang, H. (2015). Work passion through the lens of culture: Harmonious work passion, obsessive work passion, and work outcomes in Russia and China. Journal of Business and Psychology, 30, 457-471.

Caprara, G. V., \&Steca, P. (2007). Prosocial agency: The contribution of values and self-efficacy beliefs to prosocial behavior across ages. Journal of Social and Clinical Psychology, 26, 218239.

Chin, W. W. (2010). How to write up and report PLS analyses. In V. E. Vinzi, W. W. Chin, J. Henseler \& H. Wang (Eds.), Handbook of partial least squares: Concepts, methods and applications in marketing and related fields (pp. 655-690). Berlin: Springer.

Cialdini, R. B., Reno, R. R., \& Kallgren, C. A. (1990). A focus theory of normative conduct: Recycling the concept of norms to reduce littering in public places. Journal of Personality and Social Psychology, 58, 1015-1026.

Cohen, J. (1988). Statistical power analysis for the behavioural sciences (2nd ed.). Hillsdale, New Jersey: Lawrence Erlbaum Associates.

Cordano, M., Welcomer, S., Scherer, R. F., Pradenas, L., \& Parada, V. (2011). A cross-cultural assessment of three theories of proenvironmental behavior: A comparison between business students of Chile and the United States. Environmental and Behavior, 43(5), 634-357.

Das, A. K., Biswas, S. R., Munshi, M. A. K. J., \& Uddin, M. A. (2019). Corporate environmental strategy and voluntary environmental behavior-mediating effect of psychological green climate. Sustainability, 11(11), 1-17.

Deci, E. L., \& Ryan, R. M. (1985). Intrinsic motivation and selfdetermination in human behavior. New York: Plenum Press.

Education Malaysia. (2020). Malaysia higher education in brief. Retrievedfromhttps://educationmalaysia.gov.my/malaysiahigher-education-in-brief 
Faul, F., Erdfelder, E., Buchner, A., \& Lang, A.-G. (2009). Statistical power analyses using $G^{*}$ Power 3.1: Tests for correlation and regression analyses. Behavior Research Methods, 41, 1149-1160.

Fornell, C., \& Larcker, D. F. (1981). Evaluating structural equation models with unobservable variables and measurement error. Journal of Marketing Research, 18(1), 39-50.

Geissers, S. (1974). A predictive approach to the random effect model. Biometrika, 61(1), 101-107.

Gold, A. H., Malhotra, A., \& Segars, A. H. (2011). Knowledge management: An organizational capabilities perspective. Journal of Management, 18(1), 185-214.

Hair, J. F., Hult, G. T. M., Ringle, C. M., \& Sarstedt, M. (2017). A primer on partial least squares structural equation modeling (2nd ed.). Thousand Oaks, CA: Sage.

Hardgrove, M. E., \& Howard, A. P. (2015). Passion thrillers and passion killers: How to support and how to thwart employee passion. Journal of Business \& Economic Policy, 2(1), 16-22.

Henseler, J., Ringle, C. M., \& Sarstedt, M. (2015). A new criterion for assessing discriminant validity in variance-based structural equation modeling. Journal of the Academic Marketing Science, 43(1), 115-135.

Ho, V. T., Kong, D. T., Lee, C.-H., Dubreuil, P., \& Forest, J. (2018). Promoting harmonious work passion among unmotivated employees: A two-nation investigation of the compensatory function of cooperative psychological climate. Journal of Vocational Behavior, 106, 112-125.

Houlfort, N., Philippe, F. L., Bourdeau, S., \& Leduc, C. (2018). A comprehensive understanding of the relationships between passion for work and work-family conflict and the consequences for psychological distress. International Journal of Stress Management, 25(4), 313-329.

Jia, J., Liu, H., Chin, T., \&Hu, D. (2018). The continuous mediating effects of GHRM on employees' green passion via transformational leadership and green creativity. Sustainability. 10(9), 1-18.

Kim, A., Kim, Y., Han, K., Jackson, S. E., \& Ployhart, R. E. (2017). Multilevel influences on voluntary workplace green behavior: Individual differences, leader behavior, and coworker advocacy. Journal of Management, 43(5), 1335-1358.

Kim, M. S., Kim, J., \& Thapa, B. (2018). Influence of environmental knowledge on affect, nature affiliation and pro-environmental behaviors among tourists. Sustainability, 10(9), 1-16. 
Kline, R. B. (2011). Principles and practice of structural equation modeling. New York: Guilford Press.

Kock, N. (2015). Common method bias in PLS-SEM: A full collinearity assessment approach. International Journal of e-collaboration, 11(4), 1-10.

Lange, F., \&Dewitte, S. (2019). Measuring pro-environmentalbehavior: Review and recommendations. Journal of Environmental Psychology, 63, 92-100.

Lee, T. H., Jan, F. H., \& Yang, C. C. (2013) Conceptualizing and measuring environmentally responsible behaviors from the perspective of community-based tourists. Tourism Management, $36,454-468$.

Li, D., Zhao, L., Ma, S., Shao, S., \& Zhan, L. (2019). What influences an individual's pro-environmental behavior? A literature review. Resources, Convervation \& Recyling, 146, 28-34.

Lukman, R. K., Lozano, R., Vamberger, T., \& Krajnc, M. (2013). Addressing the attitudinal gap towards improving the environment: A case study from a primary school in Slovenia. Journal of Cleaner Production, 48, 93-100.

Mtutu, P., \& Thondhlana, G. (2016). Encouraging pro-environmental behaviour: Energy use and recycling at Rhodes University, South Africa. Habitat International, 53, 142-150.

Mustafa, S., \& Saad, S. (2011). Harmonizing the tenth Malaysia plan priorities with the new economic model and the green world order. International Journal of Management Studies, 18(Special Issue), 59-72.

Norton, T. A., Parker, S. L., Zacher, H., \& Ashkanasy, N. M. (2015a). Employee green behavior: A theoretical framework, multilevel review, and future research agenda. Organisation and Environment, 28(1), 103-125.

Norton, T. A., Zacher, H., \& Ashkanasy, N. M. (2014). Organisational sustainability policies and employee green behaviour: The mediating role of work climate perceptions. Journal of Environmental Psychology, 38, 49-54.

Norton, T. A., Zacher, H., \& Ashkanasy, N. M. (2015b). Proenvironmental organizational culture and climate. In J. L. Robertson, \&J. Barling(Eds), Thepsychology of green organisations. New York: Oxford University Press.

Paille, P., \& Mejia-Morelos, J. H. (2014). Antecedents of proenvironmental behaviors at work: The moderating influence 
of psychological contract breach. Journal of Environmental Psychology, 38, 124-131.

Philippe, F. L., Vallerand, R. J., Houlfort, N., Lavigne, G. L., \& Donahue, E. G. (2010). Passion for an activity and quality of interpersonal relationships: The mediating role of emotions. Journal of Personality and Social Psychology, 98, 917-932.

Ringle, C. M., Wende, S., \& Becker, J. M. (2015). SmartPLS 3. Retrieved from http:// www. Smrtpls.com.

Robertson, J. L., \& Barling, J. (2013). Greening organizations through leaders' influence on employees' pro-environmental behaviors. Journal of Organizational Behavior, 34, 176-194.

Robertson, J. L., \& Carleton, E. (2017). Uncovering how and when environmental leadership affects employees' voluntary proenvironmental behavior. Journal of Leadership \& Organizational Studies, 1-14.

Salancik, G. J., \& Pfeffer, J. (1978). A social information processing approach to job attitudes and task design. Administrative Science Quarterly, 23, 224-253.

Sani, R. (2019, January 30). Greening the campus. New Straits Times. Retrieved from https://www.nst.com.my/ education/2019/01/455787/greening-campus

Sawitri, D. R., Hadiyanto, H., Hadi, S. P. (2015). Pro-environmental behavior from a social cognitive theory perspective. Procedia Environmental Sciences, 23, 27-33.

Shadish, W. R., Cook, T. D., \& Campbell, D. T. (2002). Experimental and quasi-experimental designs for generalized causal inference. Boston, MA: Houghton, Mifflin and Company.

Stone, M. (1974). Cross-validation and multinomial prediction. Biometrika, 61(3), 509-515.

Thompson, A. A., Peteraf, M. A., Gamble, J. E., \& Strickland III, A. J. (2018). Crafting and executing strategy: The quest for competitive advantage - Concepts and cases (21st ed.). New York: McGrawHill.

UI GreenMetric. (2020). Overall ranking 2019. Retrieved from http:// greenmetric.ui.ac.id/overall-rankings-2019

United Nation (2019). Why does climate change matter? Retrieved from https://www.unenvironment.org/explore-topics/climatechange/why-does-climate-change-matter

Vallerand, R. J. (2012). The role of passion in sustainable psychology well-being. Psychology of Well-Being: Theory, Research and Practice, 2(1), 1-21. 
Vallerand, R. J., Blanchard, C., Mageau, G. A., Koestner, R., Ratelle, C., Leonard, M., et al. (2003). Les passions de l'ame: On obsessive and harmonious passion. Journal of Personality and Social Psychology, 85, 756-767.

Vallerand, R. J., Houlfort, N., \& Forest, J. (2014). Passion for work: Determinants and outcomes. In M. Gagné (Ed.). The Oxford handbook of work engagement, motivation, and self-determination theory (pp. 85-105). Oxford: Oxford University Press.

Zhao, X., Lynch, J. G., \& Chen, Q. (2010). Reconsidering Baron and Kenny: Myths and truths about mediation analysis. Journal of Consumer Research, 37(2), 197-206.

Zhou, S., Zhang, D., Lyu, C., \& Zhang, H. (2018). Does seeing "mind acts upon mind" affect green psychological climate and green product development performance? The role of matching between green transformation leadership and individual green values. Sustainability, 10, 1-21.

Zientara, P., \& Zamojska, A. (2018). Green organizational climates and employee pro-environmental behavior in the hotel industry. Journal of Sustainable Tourism, 26(7), 1142-1159. 